\title{
The Energy and Exergy Analysis of the Reactor Unit of Boric Acid Production Process with ChemCAD Simulation
}

\author{
Hakan Kizıltaş*, \\ Department of Chemical Engineering, Faculty of Engineering, Ataturk University, Erzurum, Turkey
}

\section{Keywords}

Boric Acid,

Energy and Exergy Analysis, ChemCad,

Energy and Exergy Flows,

Exergy Efficiency.

\begin{abstract}
Energy and exergy analysis of systems are of great importance to enhance the energy and exergy efficiency of industrial production facilities. With the energy and exergy analyses performed, the energy dependency of the production facilities and their energy consumption can be reduced, the price of the product can decrease, and the profit margin can increase. Additionally, it is ensured that the energy produced based on fossil fuels is used in a controlled way. In the present study, the analysis of energy and exergy has been performed for the production reactor unit of the Boric Acid from Colemanite. The first law of thermodynamics and ChemCAD simulation program was used for energy analysis calculations, and the calculations of exergy analysis were carried out by using the second law of thermodynamics. The total energy loss of the reactor unit and the calculated energy loss per $100 \mathrm{kcal}$ input steam were calculated as $110880 \mathrm{kcal} / \mathrm{h}$ and $3.724 \%$, and the losses of total exergy in the reactor units and the losses of exergy calculated per $100 \mathrm{kcal}$ input steam were calculated as $225058.86 \mathrm{kcal} / \mathrm{h}$ and $30.095 \%$, respectively. Exergy efficiency for the reactor unit has been determined as $3.3 \%$. Some suggestions were given for the reactor units of boric acid production plants to minimize system losses.
\end{abstract}

\section{Introduction}

In recent years, the continuous increase of the world population and technological developments have greatly increased the energy requirement [1]. The increase in energy demands will, on the other hand, cause the reserves of traditional energy resources to diminish soon, as a result, energy will become very expensive. Due to these reasons, the more efficient use of existing energy resources and the development of alternative energy resources have become increasingly studied topics in recent years [2, 3]. Today, the majority of industrial energy needs are provided by fossil fuels in most countries. The difficulties of transporting fossil fuels to different regions and environmental pollution problems such as the greenhouse effect and toxic gases released into the environment resulting from its burning can limit the use of these types of fuels [4]. For this reason, towards the end of the 20th century, the studies on the effective use of the resources of existing energy and the research for alternative energy sources have completely raised [5, 6].

Exergy term and exergy analysis are of great importance for humanity because of the intensive use of energy, the limited reserves of fossil fuels, which are one of our main energy resources, and cause environmental pollution $[7,8]$. The laws of thermodynamics play an important role in defining these terms [9]. The analysis of energy and exergy is a form of analysis that uses together with the first and second laws of thermodynamics and provides the use of the most efficient energy [10]. Especially, while the first law of thermodynamics is used for energy analysis, the second law provides for exergy analysis as it determines the reversible and irreversibility [11]. The purpose of exergy analysis is to enable the development of new technologies that leave less waste to the environment and use less natural resources [12].
The studies on the analyses of energy and exergy are carried out for industrial plants in different countries [13]. The studies on the analyses of energy and exergy, important for developing countries such as Turkey, are frequently carried out for industrial plants in different countries $[14,15]$. Because the use of energy in industrial areas and the resulting energy losses can be minimized by energy and exergy modeling, thus strengthening the economy of countries and reducing the environmental pollution [16].

Boron, the 51st element commonly found in the earth, is never found free and it is known that there are approximately 230 types of boron minerals [17]. Boric acid $\left(\mathrm{H}_{3} \mathrm{BO}_{3}\right)$, which has many production methods, is a boron intermediate used in many industries [18]. Some of these methods are involving the reactions of ulexite mineral with hydrochloric acid ( $\mathrm{HCl})$ [19], tincal with sulfuric acid $\left(\mathrm{H}_{2} \mathrm{SO}_{4}\right)$ [20], colemanite with sulfuric acid $\left(\mathrm{H}_{2} \mathrm{SO}_{4}\right)$ [21], tincal with nitric acid $\left(\mathrm{HNO}_{3}\right)$ [22]. In Turkey, the manufacturing of boric acid has been carried out from the colemanite method [23]. The boric acid production reaction from colemanite by sulfuric acid treatment is as follows. [24]:

$$
\mathrm{Ca}_{2} \mathrm{~B}_{6} \mathrm{O}_{11} .5 \mathrm{H}_{2} \mathrm{O}+2 \mathrm{H}_{2} \mathrm{SO}_{4}+6 \mathrm{H}_{2} \mathrm{O} \rightarrow 2 \mathrm{CaSO}_{4} \cdot 2 \mathrm{H}_{2} \mathrm{O}+6 \mathrm{H}_{3} \mathrm{BO}_{3}
$$

The reaction of the colemanite mineral, sulfuric acid, and dilute boric acid solution occurs in the reaction unit, as shown in Figure 1. For 100 $\mathrm{m}^{3}$ dilute boric acid solution, $4 \mathrm{~m}^{3} \mathrm{H}_{2} \mathrm{SO}_{4}$ and 16 tons of colemanite minerals are used [25]. The concentrated sulfuric acid and the dilute boric acid solution are mixed in a static mixer and fed into the reactor. The reaction time is about 4 hours and the reaction temperature is in the range of $80-100^{\circ} \mathrm{C}$. In the manufacturing of boric acid, four reactors are isolated and reinforced with external heating to prevent heat losses in the reaction unit. Since the reaction in the first reactor is exothermic, a heater is not used [26]. 


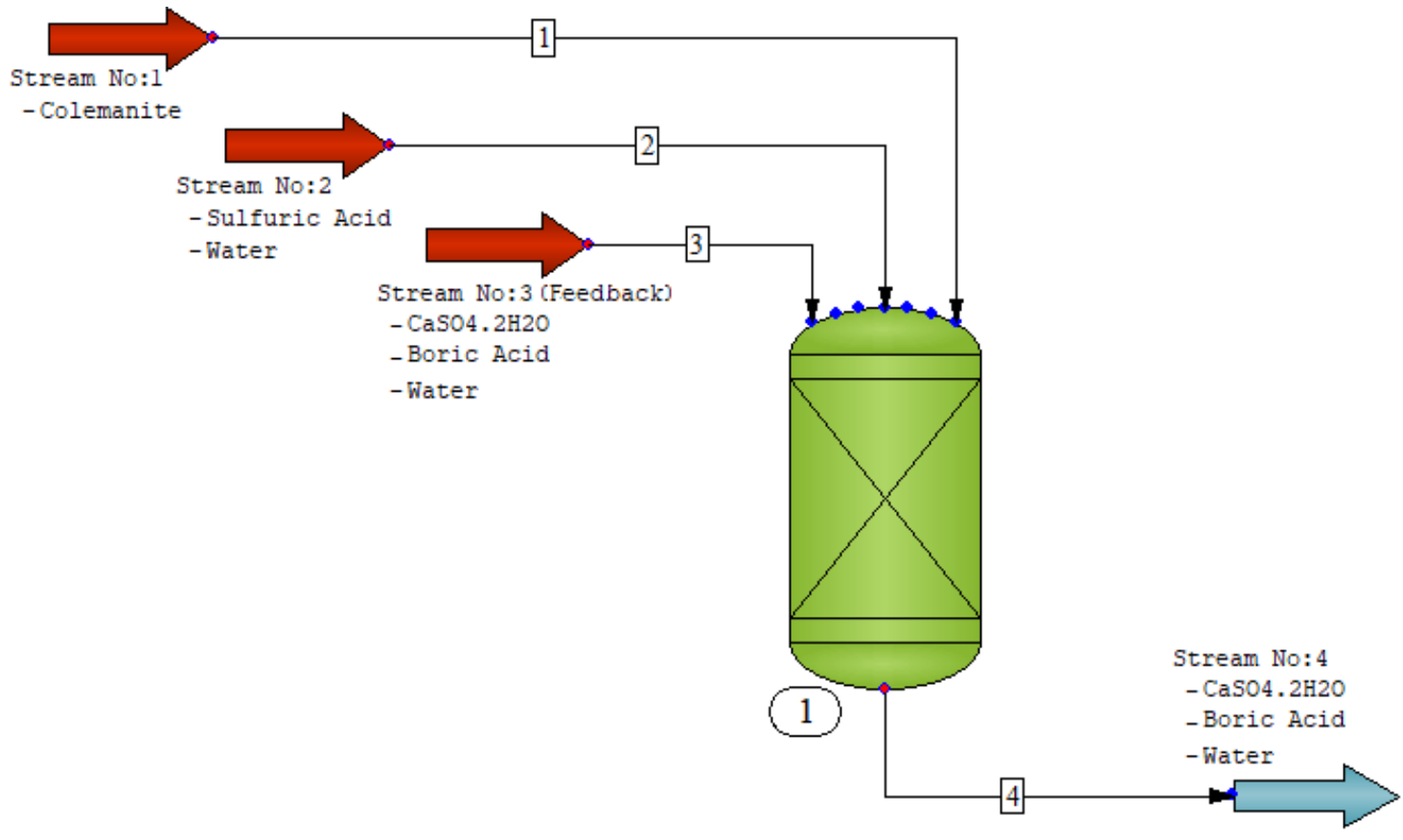

Figure 1. The reaction unit of the boric acid production

The $\mathrm{pH}$ values of the first three reactors are kept constant between 1.5 and 1.8. The reaction takes place in the first reactor by using almost all of the sulfuric acid with colemanite, while colemanite and sulfuric acid remaining unreacted in the first stage complete the reaction in other reactors. Reactors are designed to overflow from one to the other. The $2^{\text {nd }}, 3^{\text {rd }}$, and $4^{\text {th }}$ reactors are equipped with heating spirals and the tank temperatures are kept constant. In the 4 th reactor, the $\mathrm{pH}$ value should be in the range of 3-4 to remove Fe and As impurities [27]. Mixers are used in the reactors to ensure that gypsum sludge is suspended with the same characteristics at every point.

In this study, the mathematical model of the Boric Acid Production Plant was created and the model of the reactor unit, which has the highest energy loss, was designed with the ChemCAD simulation program and the results were obtained. The losses of energy and exergy in the units are calculated by performing energy and exergy analysis based on the first and second law of thermodynamics on the process, respectively.

\section{Thermodynamic design equations for Energy and Exergy Analysis}

In accord with the law of conservation of mass, the amount of matter inflow and outflow of a system must be equal. Although there are different definitions for the concept of exergy, the most general and basic definition is as follows: It is the amount of maximum beneficial work that can be achieved from the initial state to steady-state in a system with a constant flow of matter [28].

The main parameters of exergy include the terms chemical, physical, potential, and kinetic energies when specific study subjects such as electrical, magnetic, nuclear, and interfacial effects were disregarded [29]. In this case, the obtained equation of exergy could be editable as follows.

$e=\left(h-h_{0}\right)-\left(s-s_{0}\right) T_{0}+\frac{v^{2}}{2 g}+\left(z-z_{0}\right) g+e_{c h}$

where e is specific exergy $\left(\mathrm{J}_{\mathrm{kg}}{ }^{-1}\right), \mathrm{h}$ is specific enthalpy $\left(\mathrm{J} \cdot \mathrm{kg}^{-1}\right), \mathrm{s}$ is specific entropy $\left(\mathrm{J} \cdot \mathrm{kg}^{-1} \cdot \mathrm{K}^{-1}\right)$, $\mathrm{T}$ is the temperature $(\mathrm{K}), \mathrm{v}$ is the average velocity of flowing materials $\left(\mathrm{m} . \mathrm{s}^{-1}\right), \mathrm{g}$ is the gravitational acceleration $\left(\mathrm{m} . \mathrm{s}^{-2}\right), \mathrm{z}$ is the height above sea level $(\mathrm{m})$, and $\mathrm{e}_{\mathrm{ch}}$ is chemical exergy $\left(\mathrm{J} \mathrm{kg}^{-1}\right)$. The potential and kinetic terms are generally negligible in exergy analysis of chemical processes [30]. The calculation of chemical exergy of solid, liquid and gas flows for pure components and mixtures have been presented with different studies [31]. The definition of chemical exergies for heterogeneous (liquids or solids) flows is as follows:

$e_{c h}=\sum_{j}^{n} w_{j} \cdot c_{c h, j}^{\circ}$

where $\mathrm{j}$ is component, $\mathrm{n}$ is a number of components, $\mathrm{w}$ is the weight fraction of materials, and $c_{c h}^{\circ}$ is the chemical exergy of each pure component. The chemical exergy expression can be written as follows for solid or liquid materials [32].

$\mathrm{e}_{\mathrm{ch}}=\left(\sum \mathrm{x}_{\mathrm{j}} \mathrm{e}_{\mathrm{ch}, \mathrm{j}}^{\circ}+\mathrm{RT}_{0} \sum \mathrm{x}_{\mathrm{j}} \ln \left(\mathrm{a}_{\mathrm{j}}\right)\right) / \mathrm{M}_{\mathrm{j}}$

where $\mathrm{x}$ is a molar fraction, $\mathrm{a}$ is activity, and $\mathrm{M}_{\mathrm{j}}$ is mean molecular weight.

Since the conservation of exergy can be used for reversible systems, it is necessary to add the loss term (Eloss) to include irreversibilities in the study of real systems [33]. With the addition of the loss term, the exergy equation in steady-state-flow systems is as follows:

$\sum_{\text {in }} m . e+\sum_{\text {in }} E_{Q}+W_{\text {in }}=\sum_{\text {out }} m \cdot e+\sum_{\text {out }} E_{Q}+E_{\text {loss }}$

where, $E_{Q}$ is the exergy of heat transferred $\left(Q_{h}\right)$ from a heat source.

$\mathrm{E}_{\mathrm{Q}}=Q_{h}\left(\frac{T_{H}-T_{0}}{T_{H}}\right)$

The exergy performance of the systems can be evaluated by considering the different conditions. According to a defined definition, the exergy performance is the proportion of the total exergy of beneficial products to the total exergy obtained by the feeding substances into the system and is expressed as follows [34]:

$\mu=\frac{\sum \text { (Exergies of beneficial products) }}{\text { Feeding exergies }}$

$\mu=\frac{\sum_{\text {out }}(\mathrm{m} . \mathrm{e})_{\mathrm{P}}}{\sum_{\text {in }}(\mathrm{m} \cdot \mathrm{e})_{\mathrm{r}}+\mathrm{m}_{\mathrm{f}} \mathrm{e}_{\mathrm{f}}+\sum_{\text {in }} \mathrm{E}_{\mathrm{Q}}+\mathrm{W}_{\text {in }}}$

$\mu$ is a measure of exergy performance used for processes in which products or products are produced with one or more chemical reactions. According to another definition, exergy performance is the proportion of the total exergy of the beneficial products to the total exergy obtained by the substances fed into the system for systems where chemical exergy is eliminated and more heat exchange is experienced and is expressed as follows [35]: 
$\eta=\frac{\text { Effect of beneficial exergy }}{\text { Driving exergy }}$

$\eta=\frac{\sum_{\text {out }}(\mathrm{m} \cdot \mathrm{e}) \mathrm{P}-\sum_{\text {in }}(\mathrm{m} \cdot \mathrm{e})_{\mathrm{r}}}{\mathrm{m}_{\mathrm{f}} \mathrm{e}_{\mathrm{f}}+\sum_{\text {in }} \mathrm{E}_{\mathrm{Q}}+\mathrm{W}_{\text {in }}}$

$\eta$ is a measure of exergy performance used for systems involving more thermal and separation processes.

The values of enthalpy and entropy for chemicals used in the process of producing boric acid were calculated using the Shomate equations given below [36]:

$\overline{\mathrm{h}}-\overline{\mathrm{h}}_{0}=\mathrm{A} \cdot \mathrm{t}+\mathrm{B} \frac{\mathrm{t}^{2}}{2}+\mathrm{C} \frac{\mathrm{t}^{3}}{3}+\mathrm{D} \frac{\mathrm{t}^{4}}{4}-\mathrm{E} \frac{1}{\mathrm{t}}+\mathrm{F}-\mathrm{H}$

$\overline{\mathrm{s}}=\mathrm{A} \cdot \ln (\mathrm{t})+\mathrm{B} \cdot \mathrm{t}+\mathrm{C} \frac{\mathrm{t}^{2}}{2}+\mathrm{D} \frac{\mathrm{t}^{3}}{3}-\mathrm{E} \frac{1}{2 \cdot \mathrm{t}^{2}}+\mathrm{G}$

where $t$ is the temperature $(\mathrm{K}) / 1000$ and the constant values of $\mathrm{A}, \mathrm{B}, \mathrm{C}$, $\mathrm{D}, \mathrm{E}, \mathrm{F}, \mathrm{H}$, and $\mathrm{G}$ for each component.

For colemanite $\left(\left(\bar{h}_{f}^{0}(\mathrm{~kJ} / \mathrm{mol})=-6939.6, \bar{s}_{0}(\mathrm{~J} / \mathrm{mol} . \mathrm{K})=383.7\right)[37]\right.$ :

$\overline{\mathrm{h}}=51.32456 \mathrm{t}-58.5312 \frac{\mathrm{t}^{2}}{2}+111.4752 \frac{\mathrm{t}^{3}}{3}-34.53968 \frac{\mathrm{t}^{4}}{4}+$

$0.054876 \frac{1}{\mathrm{t}}-12.35976$

$\overline{\mathrm{s}}=51.32456 \ln (\mathrm{t})-58.5312 \mathrm{t}+111.4752 \frac{\mathrm{t}^{2}}{2}-34.53968 \frac{\mathrm{t}^{3}}{3}+$

$0.054876 \frac{1}{2 . t^{2}}++276.4583$

For $\mathrm{H}_{2} \mathrm{SO}_{4}\left(\bar{h}_{f}^{0}(\mathrm{~kJ} / \mathrm{mol})=-735.13, \bar{s}_{0}(\mathrm{~J} / \mathrm{mol} . \mathrm{K})=298.78\right)[38]$ :

$\overline{\mathrm{h}}=47.28924 \mathrm{t}+190.3314 \frac{\mathrm{t}^{2}}{2}+-148.1299 \frac{\mathrm{t}^{3}}{3}+43.86631 \frac{\mathrm{t}^{4}}{4}+$

$0.740016 \frac{1}{\mathrm{t}}-758.9525$

$\overline{\mathrm{s}}=47.28924 \ln (\mathrm{t})+190.3314 \mathrm{t}-148.1299 \frac{\mathrm{t}^{2}}{2}+43.86631 \frac{\mathrm{t}^{3}}{3}+$

$0.740016 \frac{1}{2 . t^{2}}+301.2961$

For $\mathrm{H}_{2} \mathrm{O}\left(\bar{h}_{f}^{0}(\mathrm{~kJ} / \mathrm{mol})=-241.83, \bar{s}_{0}(\mathrm{~J} / \mathrm{mol} . \mathrm{K})=188.84\right)[38]$ :

$\overline{\mathrm{h}}=30.092 \mathrm{t}+6.832514 \frac{\mathrm{t}^{2}}{2}+6.793435 \frac{\mathrm{t}^{3}}{3}-2.534480 \frac{\mathrm{t}^{4}}{4}-$ $0.082139 \frac{1}{t}-250.8810$

$\overline{\mathrm{s}}=30.092 \ln (\mathrm{t})+6.832514 \mathrm{t}+6.793435 \frac{\mathrm{t}^{2}}{2}-2.534480 \frac{\mathrm{t}^{3}}{3}-$

$0.082139 \frac{1}{2 . t^{2}}+223.3967$

For Boric Acid $\left(\bar{h}_{f}^{0}(\mathrm{~kJ} / \mathrm{mol})=-992.28, \bar{s}_{0}(\mathrm{~J} / \mathrm{mol} . \mathrm{K})=295.23\right)[38]$ :

$\overline{\mathrm{h}}=22.91803 . \mathrm{t}+182.0312 \frac{\mathrm{t}^{2}}{2}-125.7518 \frac{\mathrm{t}^{3}}{3}+34.68749 \frac{\mathrm{t}^{4}}{4}+$

$0.145463 \frac{1}{\mathrm{t}}-1006.649$

$\overline{\mathrm{s}}=22.91803 \cdot \ln (\mathrm{t})+182.0312 . \mathrm{t}-125.7518 \frac{\mathrm{t}^{2}}{2}+34.68749 \frac{\mathrm{t}^{3}}{3}+$

$0.145463 \frac{1}{2 . t^{2}}+273.1524$

For Calcium Sulfate Dihydrate $\left(\bar{h}_{f}^{0}(\mathrm{~kJ} / \mathrm{mol})=-2021.1, \bar{s}_{0}(\mathrm{~J} / \mathrm{mol} . \mathrm{K})=\right.$ 193.97) [38]:

$\overline{\mathrm{h}}=35.056 \mathrm{t}-182.5852 \frac{\mathrm{t}^{2}}{2}+290.1912 \frac{\mathrm{t}^{3}}{3}-65.91123 \frac{\mathrm{t}^{4}}{4}+$

$0.246782 \frac{1}{\mathrm{t}}-346.5864$

$\overline{\mathrm{s}}=35.056 \ln (\mathrm{t})-182.5852 \mathrm{t}+290.1912 \frac{\mathrm{t}^{2}}{2}-65.91123 \frac{\mathrm{t}^{3}}{3}+$

$0.246782 \frac{1}{2 . t^{2}}++225.8765$

\section{Results and Discussion}

To perform the thermodynamic analysis for the reactor unit of the boric acid production system, the first law of thermodynamics was firstly analyzed. The energy inputs, outputs, and losses of the reactor unit for boric acid production, determined by the calculation and the ChemCAD simulation program (as shown in Figure 2), were given per $100 \mathrm{~kJ} / \mathrm{h}$ of input energy (enthalpy) in Table 1, and the energy band diagram was given in Figure 3.

Table 1. The energy inputs, outputs, and losses of the reactor unit

\begin{tabular}{|c|c|c|c|c|c|}
\hline Steam & Material & & $\begin{array}{c}\text { Enthalpy } \\
(\mathrm{kJ} / \mathrm{h})\end{array}$ & $\begin{array}{c}\text { per } 100 \\
\mathrm{~kJ} / \mathrm{h} \text { of } \\
\text { input } \\
\text { enthalpy } \\
(\mathrm{kJ})\end{array}$ & $\begin{array}{l}\text { Percent } \\
\text { age (\%) }\end{array}$ \\
\hline $\begin{array}{l}\text { Steam } 1 \\
\text { (input) }\end{array}$ & Colemanite & & 26400 & 0.887 & 0.887 \\
\hline $\begin{array}{l}\text { Steam } 2 \\
\text { (input) }\end{array}$ & $\begin{array}{l}\text { Sulphuric } \\
\text { Acid (96\%) } \\
\text { Boric Acid }\end{array}$ & & 18934 & 0.636 & 0.636 \\
\hline $\begin{array}{c}\text { Steam } 3 \\
\text { (input) }\end{array}$ & $\begin{array}{l}\text { + Calcium } \\
\text { Sulfate } \\
\text { Dehydrate } \\
\text { + Water }\end{array}$ & & 1062182 & 35.675 & 35.675 \\
\hline $\begin{array}{l}\text { Heating } \\
\text { (Q) }\end{array}$ & $\begin{array}{l}\text { Saturated } \\
\text { vapor at } \\
\text { bars }\end{array}$ & 8 & 1869847 & 62.802 & 62.802 \\
\hline $\begin{array}{c}\text { Total } \\
\text { (input) }\end{array}$ & & & 2977363 & 100 & 100 \\
\hline $\begin{array}{c}\text { Steam } 4 \\
\text { (output) }\end{array}$ & $\begin{array}{l}\text { Boric Acid } \\
\text { + Calcium } \\
\text { Sulfate } \\
\text { Dehydrate } \\
\text { + Water }\end{array}$ & & 2866483 & 96.276 & 96.276 \\
\hline $\begin{array}{c}\text { Heat loss } \\
\left(Q_{\text {loss }}\right)\end{array}$ & & & 110880 & 3.724 & 3.724 \\
\hline $\begin{array}{c}\text { Total } \\
\text { (output) }\end{array}$ & & & 2977363 & 100 & 100 \\
\hline
\end{tabular}

Table 2. The exergy inputs, outputs, and losses of the reactor unit

\begin{tabular}{|c|c|c|c|c|}
\hline Steam & Material & $\begin{array}{c}\text { Exergy } \\
(\mathrm{kJ} / \mathrm{h})\end{array}$ & $\begin{array}{c}\text { per } 100 \\
\mathrm{~kJ} / \mathrm{h} \text { of } \\
\text { input } \\
\text { exergy } \\
(\mathrm{kJ})\end{array}$ & $\begin{array}{l}\text { Percen- } \\
\text { tage (\%) }\end{array}$ \\
\hline $\begin{array}{c}\text { Steam } 1 \\
\text { (input) }\end{array}$ & Colemanite & 768 & 0.09062 & 0.09062 \\
\hline $\begin{array}{c}\text { Steam } 2 \\
\text { (input) }\end{array}$ & $\begin{array}{l}\text { Sulphuric } \\
\text { Acid (96\%) } \\
\text { Boric Acid }\end{array}$ & 617.3 & 0.07284 & 0.07284 \\
\hline $\begin{array}{c}\text { Steam } 3 \\
\text { (input) }\end{array}$ & $\begin{array}{l}\text { + Calcium } \\
\text { Sulfate } \\
\text { Dehydrate } \\
\text { + Water }\end{array}$ & 70051.8 & 8.26564 & 8.26563 \\
\hline $\begin{array}{l}\text { Heating } \\
\text { (Q) }\end{array}$ & $\begin{array}{c}\text { Saturated } \\
\text { vapor at } 8 \\
\text { bars }\end{array}$ & 776069.3 & 91.5709 & 91.57091 \\
\hline $\begin{array}{c}\text { Total } \\
\text { (input) }\end{array}$ & & 847506.4 & 100 & 100 \\
\hline $\begin{array}{c}\text { Steam } 4 \\
\text { (output) }\end{array}$ & $\begin{array}{l}\text { Boric Acid } \\
\text { +Calcium } \\
\text { Sulfate } \\
\text { Dehydrate } \\
\text { + Water }\end{array}$ & 592447.5 & 69.9048 & 69.90478 \\
\hline $\begin{array}{c}\text { Heat loss } \\
\left(Q_{\text {loss }}\right)\end{array}$ & & 225058.9 & 30.0952 & 30.09522 \\
\hline $\begin{array}{c}\text { Total } \\
\text { (output) }\end{array}$ & & 847506.4 & 100 & 100 \\
\hline
\end{tabular}




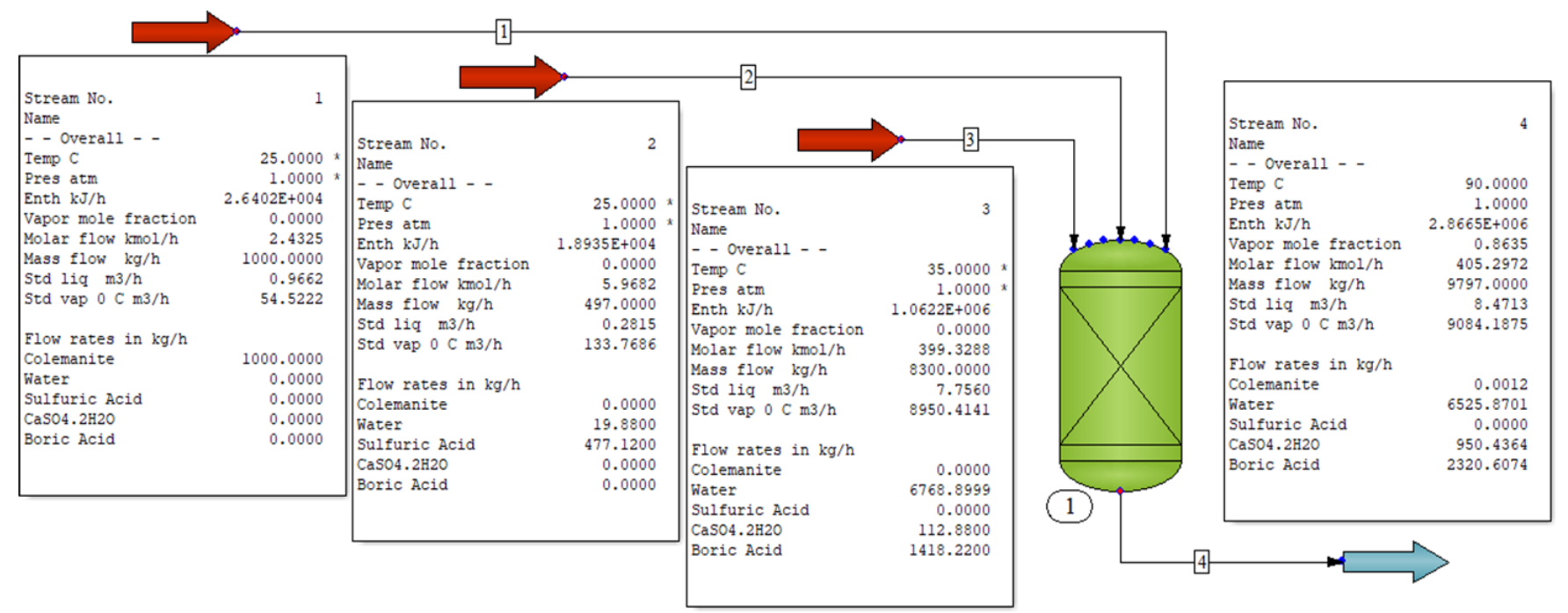

Figure 2. The ChemCAD simulation of the reactor unit and streams

As can be seen from the Table 1 and the Figure 3, it is seen that the stream with the highest enthalpy percentage is the heating water. Besides, the ascending sort of enthalpy amounts is the $1^{\text {st }}, 2^{\text {nd }}$, and $3^{\text {rd }}$ streams, respectively. In addition, approximately $96.3 \%$ of the total input enthalpy is the output stream enthalpy ( $4^{\text {th }}$ stream), while $3.7 \%$ of the enthalpy is heat lost despite a heat insulation.

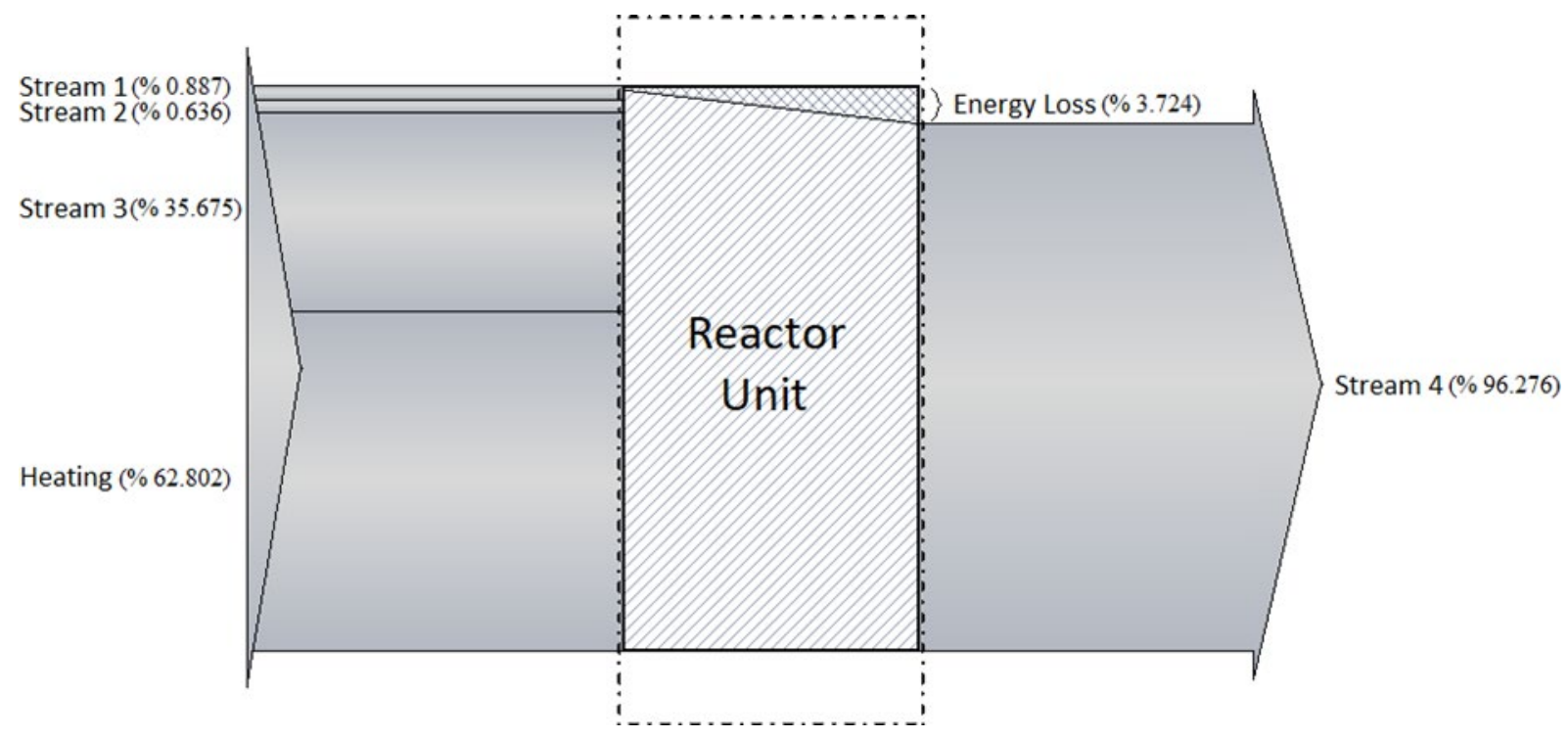

Figure 3. The energy band diagram of the reactor unit

To determine the exergy analysis the reactor unit of the boric acid production system, the second law of thermodynamics was analyzed. Table 2 and Figure 4 show the exergy inputs, outputs, and losses of the reactor unit for boric acid production calculated by using Equation 1. 


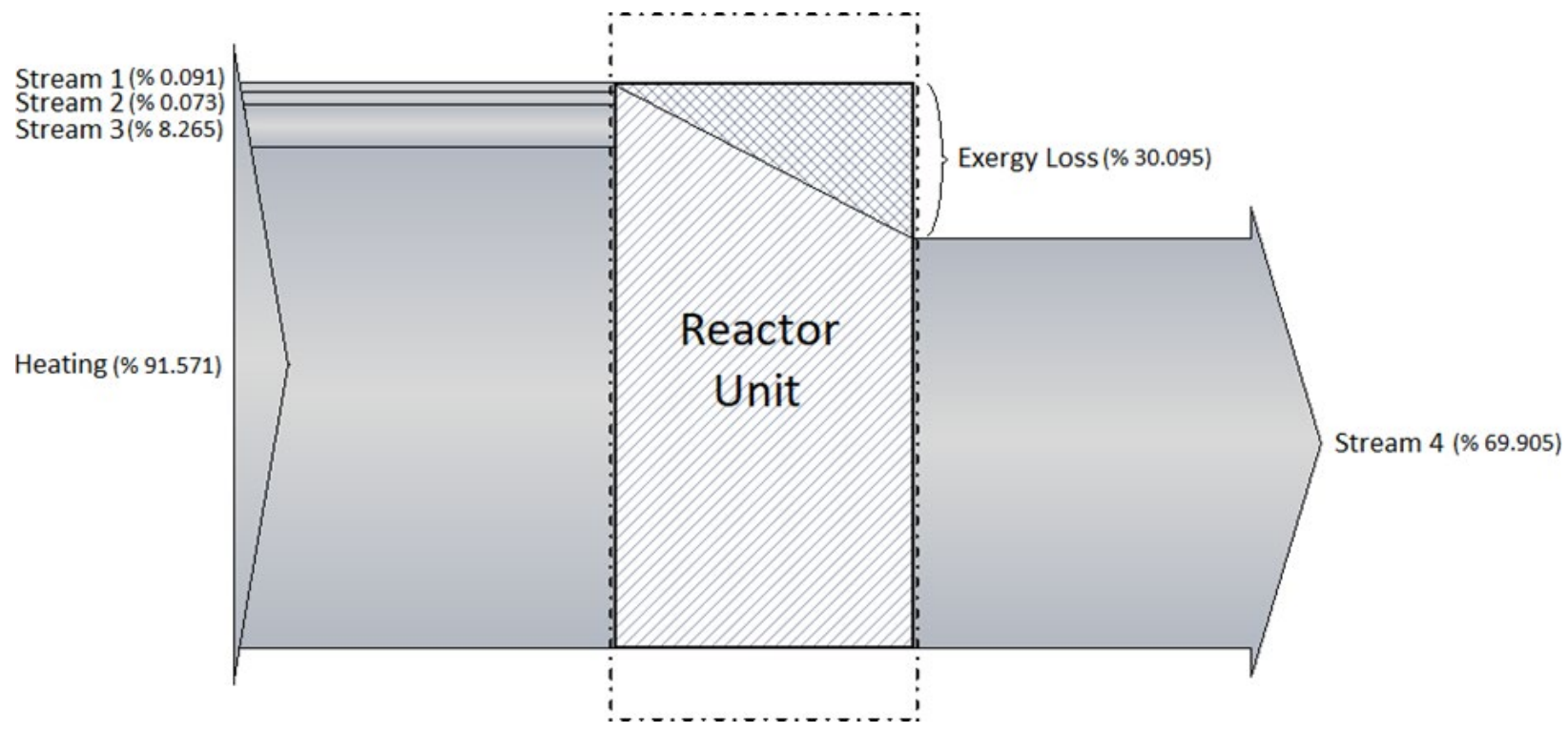

Figure 4. The exergy band diagram of the reactor unit

Exergy values are similar to the enthalpy values, it can be comprehensible in Table 2 and Figure 4 that the highest exergy input $(91.571 \%)$ is the heating system. Input exergy for $1^{\text {st }}, 2^{\text {nd }}$, and $3^{\text {rd }}$ streams are about $0.091 \%, 0.073 \%$, and $8.266 \%$ respectively. Additionally, while the exergy percentage of the output stream ( $^{\text {th }}$ stream) is approximately 69.905, the lost exergy amount is approximately $30.095 \%$.

The exergy performance of the reactor system was calculated by accepting boric acid as a useful product and colemanite and sulfuric acid as feeding material. The exergy performance of the system was calculated to be 0.033 by using Equation 7 .

\section{Conclusion}

In this study, according to the first law of thermodynamics, the total energy loss of the reactor unit and the energy loss calculated per 100 $\mathrm{kcal}$ of input currents were calculated as $110880 \mathrm{kcal} / \mathrm{h}$ and $3.724 \%$, respectively. In accord with the second law of thermodynamics, the exergy losses in reactor units and exergy losses calculated per 100 $\mathrm{kcal}$ of input flows were calculated as $225058.86 \mathrm{kcal} / \mathrm{h}$ and $30.09522 \%$, respectively.

To prevent the loss of heat to the environment as a result of the reaction, good insulation can be made to the reaction tanks and lines and a new design can be created. These losses occurring in the reaction unit are due to the irreversible exergy losses of the reactions.

A system cannot work with $100 \%$ efficiency by eliminating all exergy losses according to thermodynamic laws. During the process, the energy transmitted to the system as heat or work is transmitted from the system to its environment as energy or stored as internal energy. Energy cannot be consumed or produced but transforms into different forms of energy during the process. The common result of the first and second laws of thermodynamics is that what is consumed in thermal systems is the ability of energy to do work and that the ability of energy to do work is reduced or lost during the process. For this reason, improvements and modernizations to be made in the reactor system do not eliminate all exergy losses. However, even a small increase in efficiency to be achieved as a result of the improvements to be made will bring high profitability in total.

\section{Declaration of Conflict of Interests}

The author declares that there is no conflict of interest. They have no known competing financial interests or personal relationships that could have appeared to influence the work reported in this paper.

\section{References}

[1.] Lu, S., Zhang, X., Peng, H., Skitmore, M., Bai, X., Zheng, Z., The energy-food-water nexus: Water footprint of Henan-HubeiHunan in China. Renewable and Sustainable Energy Reviews 135 (2021) 110417.

[2.] Rafique, M., Mubashar, R., Irshad, M., Gillani, S., Tahir, M. B. Khalid, N., Yasmin, A., Shehzad, M. A. A comprehensive study on methods and materials for Photocatalytic water splitting and hydrogen production as a renewable energy resource. Journal of Inorganic and Organometallic Polymers and Materials 30 (2020) 3837-3861.

[3.] Lisin, E., Kurdiukova, G., Energy Supply System Development Management Mechanisms from the Standpoint of Efficient Use of Energy Resources. In IOP Conference Series: Earth and Environmental Science 666 (2021) 062090.

[4.] Kulagin, V.A., Grushevenko, D.A., Kapustin, N.O., Fossil fuels markets in the "energy transition" era. Russian Journal of Economics 6 (2020) 424-436.

[5.] Perevozova, I., Maksimenko, T., Bondarenko, S., Evaluation of the efficiency of enterprises in the transition to alternative (helio) energy sources. Journal of Scientific Papers «Social development and Security» 4 (2020) 174-191.

[6.] Fan, V. H., Dong, Z., Meng, K., Integrated distribution expansion planning considering stochastic renewable energy resources and electric vehicles. Applied Energy 278 (2020) 115720.

[7.] Ghasemi-Mobtaker, H., Mostashari-Rad, F., Saber, Z., Chau, K.w., Nabavi-Pelesaraei, A., Application of photovoltaic system to modify energy use, environmental damages and cumulative exergy demand of two irrigation systems-A case study: Barley production of Iran. Renewable Energy 160 (2020) 1316-1334.

[8.] Yesilyurt, M.K., The examination of a compression-ignition engine powered by peanut oil biodiesel and diesel fuel in terms of energetic and exergetic performance parameters. Fuel 278 (2020) 118319.

[9.] Cavalcanti, E. J., Carvalho, M., da Silva, D. R., Energy, exergy and exergoenvironmental analyses of a sugarcane bagasse power cogeneration system. Energy Conversion and Management 222 (2020) 113232. 
[10.] Kayaci, N., Energy and exergy analysis and thermo-economic optimization of the ground source heat pump integrated with radiant wall panel and fan-coil unit with floor heating or radiator. Renewable Energy 160 (2020) 333-349.

[11.] Kalbasi, R., Shahsavar, A., Afrand, M., Incorporating novel heat recovery units into an AHU for energy demand reductionexergy analysis. J Therm Anal Calorim 139 (2020) 2821-2830.

[12.] Khounani, Z., Hosseinzadeh-Bandbafha, H., Nazemi, F., Shaeifi, M., Karimi, K., Tabatabaei, M., Aghbashlo, M., Lam, S.S., Exergy analysis of a whole-crop safflower biorefinery: A step towards reducing agricultural wastes in a sustainable manner. Journal of environmental management 279 (2020) 111822.

[13.] Hamayun, M.H., Hussain, M., Shafiq, I., Ahmed, A., Park, Y.K. Investigation of the thermodynamic performance of an existing steam power plant via energy and exergy analyses to restrain the environmental repercussions: A simulation study. Environmental Engineering Research 27 (2022) 200683.

[14.] Yildiz, I., Caliskan, H., Energy and exergy prices of the jet kerosene fuel with carbon emission equivalents for the air transport sector in Turkey. Aircraft Engineering and Aerospace Technology 93 (2020) 457-461.

[15.] Malik, A., Qureshi, S. R., Abbas, N., Zaidi, A.A., Energy and exergy analyses of a solar desalination plant for Karachi Pakistan. Sustainable Energy Technologies and Assessments 37 (2020) 100596

[16.] Said, Z., Hachicha, A.A., Aberoumand, S., Yousef, B.A., Sayed, E.T., Bellos, E., Recent advances on nanofluids for low to medium temperature solar collectors: energy, exergy, economic analysis and environmental impact. Progress in Energy and Combustion Science 84 (2021) 100898.

[17.] Alpaydın, S..G., Aksoy, Y., The effects of colemanite and ulexite additives on the geotechnical index properties of bentonite and sand-bentonite mixtures. In Proceedings of ChinaEurope Conference on Geotechnical Engineering 1 (2018) 778 781.

[18.] Gönen, M., Rodene, D. D., Panda, S., Akcil, A. Techno-economic Analysis of Boric Acid Production from Colemanite Minera and Sulfuric Acid. Mineral Processing and Extractive Metallurgy Review (2021) 1-9.

[19.] Yarar, B., Recovery of boric acid from ulexite by leaching with hydrochloric acid derived from waste chlorine gas and froth flotation. Journal of Applied Chemistry and Biotechnology 26 (1976) 91-96.

[20.] Gezer, B., Kose, U. Ultrasonic-assisted extraction and swarm intelligence for calculating optimum values of obtaining boric acid from tincal mineral. Processes 7 (2019) 30

[21.] Gür, A., Dissolution mechanism of colemanite in sulphuric acid solutions. Korean Journal of Chemical Engineering 24 (2007) 588-591.

[22.] Tunc, M., Irem, H., Kocakerim, M.M., Copur, M., Küçük, Ö., The Conversion Kinetics of Tincal to Boric Acid in Nitric Acid Solutions. Iranian Journal of Chemistry and Chemical Engineering (IJCCE) 29 (2020) 83-90.

[23.] Künkül, A., Aslan, N.E., Ekmekyapar, A., Demirkıran, N., Boric acid extraction from calcined colemanite with ammonium carbonate solutions. Industrial \& engineering chemistry research 51 (2012) 3612-3618.

[24.] Bulutcu, A., Ertekin, C., Celikoyan, M.K., Impurity control in the production of boric acid from colemanite in the presence of propionic acid. Chemical Engineering and Processing: Process Intensification 47 (2008) 2270-2274.
[25.] İpekoglu, Ü., Polat, M. Bor endüstrisine genel bakış. Bilimsel Madencilik Dergisi 26 (1987) 5-16.

[26.] Görhan, G. Bor oksit ve borik asit katkısının kil tuğlası özelliklerine etkisi. Selçuk-Teknik Dergisi 11 (2012) 96-109.

[27.] Sayan, P., Ulrich, J., Effect of various impurities on the metastable zone width of boric acid. Crystal Research and Technology 36 (2001) 411-417.

[28.] Tekin, T., Bayramoğlu, M., Exergy and structural analysis of raw juice production and steam-power units of a sugar production plant. Energy 26 (2001) 287-297.

[29.] Tekin, T., Bayramoğlu, M., Exergy analysis of the sugar production process from sugar beets. International Journal of Energy Research 22 (1998) 591-601.

[30.] Tekin, T., Bayramoglu, M., Energy loss minimization analysis of sugar production process from sugar beet. Food and bioproducts processing: transactions of the Institution of Chemical Engineers 76 (1998) 149-154.

[31.] Xiang, J., Cali, M., Santarelli, M., Calculation for physical and chemical exergy of flows in systems elaborating mixed-phase flows and a case study in an IRSOFC plant. International Journal of Energy Research 28 (2004) 101-115.

[32.] Song, G., Xiao, J., Zhao, H., Shen, L. A unified correlation for estimating specific chemical exergy of solid and liquid fuels. Energy 40 (2012) 164-173.

[33.] Lucia, U. Entropy and exergy in irreversible renewable energy systems. Renewable and Sustainable Energy Reviews 20 (2013) 559-564.

[34.] Aghbashlo, M., Tabatabaei, M., Rastegari, H., Ghaziaskar, H.S., Valijanian, E., Exergy-based optimization of a continuous reactor applied to produce value-added chemicals from glycerol through esterification with acetic acid. Energy 150 (2018) 351-362.

[35.] Yildirim, N., Genc, S., Energy and exergy analysis of a milk powder production system. Energy Conversion and Management 149 (2017) 698-705.

[36.] Karapekmez, A., Dincer, I., Modelling of hydrogen production from hydrogen sulfide in geothermal power plants. International Journal of Hydrogen Energy 43 (2018) 1056910579

[37.] Anovitz, L.M., Hemingway, B.S., Boron. In Chapter 5. Thermodynamics of Boron Minerals: Summary of Structural, Volumetric and Thermochemical Data (2018) 181-262.

[38.] Chase, M. W. J. NIST-JANAF Thermochemical Tables, American Inst. of Physics, (1998).

\section{How to Cite This Article}

Kiziltas, H., The energy and exergy analysis of the reactor unit of Boric Acid production process with ChemCAD Simulation, Brilliant Engineering, 2 (2022), 4617. https://doi.org/10.36937/ben.2022.4617 